\author{
Danuta Piróg \\ Uniwersytet Pedagogiczny \\ im. Komisji Edukacji Narodowej \\ w Krakowie
}

\title{
Uwarunkowania przedsiębiorczości absolwentów szkół wyższych: założenia teoretyczne i stan rzeczywisty
}

\author{
Determinants of entrepreneurship of higher education graduates: theoretical \\ assumptions vs. reality
}

\begin{abstract}
Streszczenie
Przedsiębiorczość osób młodych, pojmowana zarówno jako deklaratywna gotowość do rozpoczęcia działalności gospodarczej, przekonanie o posiadaniu kompetencji w tym zakresie, jak i jako rzeczywiste samozatrudnienie, jest uznawana za korzystny czynnik rozwoju. Zwiększa ona, m.in.: innowacyjność gospodarki i prawdopodobieństwo wykreowania nowych miejsc pracy, a także buduje wysoką samoocenę podmiotu. Szczególnie istotne, z punktu widzenia podnoszenia konkurencyjności regionu, jest wybieranie kariery przedsiębiorcy przez nowo promowanych absolwentów szkół wyższych. Zakłada się, że absolwenci z wyższym wykształceniem powinni być optymalnie przygotowani do samozatrudnienia, a badania wskazują, że studenci deklarują wysokie zainteresowanie taką ścieżką zawodową.

Celem artykułu jest analiza wyników teoretycznych prac poświęconych namysłowi nad czynnikami odpowiadającymi za kreowanie postaw przedsiębiorczych. Szczególną uwagę skierowano nie tylko na rolę kształcenia akademickiego w przygotowaniu absolwentów do zakładania działalności gospodarczej, lecz także na jej efektywność w tym zakresie, co weryfikowano wynikami badań empirycznych, diagnozujących rzeczywisty odsetek przedsiębiorców w populacji nowo promowanych absolwentów.
\end{abstract}

\begin{abstract}
Entrepreneurship of young people, understood both as declared readiness to start a business, high evaluation of competences in this area and actual opening a business is perceived as a very profitable factor in development. It boosts innovation in the economy, the creation of new work places and builds high self-esteem. Especially important, from the point of regional development and its competitiveness is when a business is established by higher education graduates. They should be optimally prepared for this task and they declare a strong interest in becoming self-employed. The aim of this article is to analyse various theoretical studies devoted to the role of different determinants responsible for creating entrepreneurship. A special attention is paid to not only the role of higher education institutions in preparing their graduates for setting up their own businesses, but also to its effectiveness. It was verified by the results of an empirical survey, which diagnoses the real percentage of new graduates opening a firm.
\end{abstract}

Słowa kluczowe: absolwent; czynniki; przedsiębiorczość; rynek pracy; studia wyższe Key words: determinants; entrepreneurship; graduate; higher education; labour market 


\section{Wstęp}

Przedsiębiorczość absolwentów jest korzystna zarówno dla nich samych, jak i dla społeczeństwa oraz rozwoju gospodarczego regionu. Z perspektywy rynku pracy, najbardziej pożądana jest przedsiębiorczość pojmowana jako zakładanie własnej działalności gospodarczej, bowiem przyczynia się ona do kreowania nowych miejsc pracy, redukuje poziom bezrobocia, pobudza konkurencję i aktywizuje inne osoby do samozatrudnienia (Cranmer, 2006). Rozpatrując profity psychologiczne i socjologiczne, płynące z takiego działania, należy podkreślić, że są nimi zwłaszcza: budowanie wysokiej samooceny i wiary we własne możliwości, stymulowanie kreatywności, obniżanie ryzyka deterioracji kompetencji nabytych na danym szczeblu kształcenia przez bezpośrednie zastosowanie przynajmniej części z nich, redukcja napięć i negatywnych emocji związanych z bezskutecznym poszukiwaniem pracy (Sztumski, 1999; Czarnecki, 2006; Rożnowski, 2009).

Podjęcie decyzji o założeniu własnej działalności gospodarczej i realne wdrożenie tego zamiaru ma wielorakie uwarunkowania, ale bezsprzecznie jest konsekwencją przedsiębiorczej postawy podmiotu, którą determinują rozliczne czynniki wewnętrzne i zewnętrzne. Przeprowadzono badania, według których znaczącą determinantą zewnętrzną jest edukacja, a jej korzystny wpływ na wspieranie kreowania postaw przedsiębiorczych oraz podnoszenie poziomu samozatrudnienia rośnie wraz z etapem kształcenia (Bates, 1990).

Celem niniejszego artykułu jest przegląd prac poświęconych namysłowi nad czynnikami determinującymi kreowanie postaw przedsiębiorczych i realne zakładanie działalności gospodarczej, ze szczególnym uwzględnieniem kształcenia na poziomie akademickim. Wnioski ze studiów teoretycznych poddano empirycznej weryfikacji przez analizę wyników badań diagnostycznych absolwentów wybranych uczelni w zakresie zarówno gotowości do zakładania własnej firmy, jak i rzeczywistego odsetka przedsiębiorców w populacji nowo promowanych absolwentów ${ }^{1}$.

\section{Czynniki warunkujące przedsiębiorczość}

W rozważaniach poświęconych uwarunkowaniom przedsiębiorczości i wyborowi ścieżki kariery zawodowej przez samozatrudnienie oraz źródłom postaw przedsiębiorczych wyodrębniane są determinanty zewnętrzne i wewnętrzne, które tworzą cztery grupy czynników współdziałających ze sobą. Są to, w porządku alfabetycznym: indywidualne/osobowe cechy jednostki, kapitał społeczny/uwarunkowanie społeczne, potencjał/kapitał kompetencyjno-kwalifikacyjny (wykształcenie i doświadczenie) i uwarunkowania zewnętrzne (kontekst makroekonomiczny) (Greene, Saridakis, 2008; Livanos, 2009; Cieślik, 2010).

\section{Edukacja}

Ze względu na cel opracowania analiza czynników rozpoczyna się od grupy kapitału kompetencyjno/kwalifikacyjnego. Do niej zaliczana jest edukacja, której siła pozytywnego oddziaływania rośnie wraz z poziomem kształcenia. Zakłada się, że nabycie szerokiego wachlarza kompetencji opanowanych na najwyższym poziomie motywuje do samozatrudnienia i minimalizuje, szczególnie w pierwszym etapie, koszty inicjowanej działalności (Henley, 2009). Stwierdzono, że kształcenie akademickie bez wątpienia zapewnia warunki do zakumulowania u podmiotu dużego pakietu wiedzy i umiejętności. To usprawnia i przyspiesza nabywanie kolejnych, nowych zasobów informacji, niezbędnych do prowadzenia własnej działalności (Minniti, Bygrave, 2001).

\footnotetext{
${ }^{1}$ Osób, które ukończyły studia w okresie nie dłuższym niż 12 miesięcy.
} 
Pozytywny wpływ nie tyle edukacji na poziomie wyższym, co wsparcia przez instytucje oferujące studiowanie, może być konsekwencją różnorodnej pomocy w procesie konceptualizacji i wcielania konkretnego pomysłu na samozatrudnienie. Dedykowane realizacji tego celu są akademickie inkubatory przedsiębiorczości. Trudne do przecenienia są także zbudowane w tym środowisku sieci kontaktów społecznych, nieformalne źródła informacji i wsparcia oraz możliwość skorzystania z bezpłatnego, specjalistycznego doradztwa (Chrabąszcz, 2011).

Te teoretyczne założenia znajdują potwierdzenie w badaniach empirycznych, ustalających, że absolwenci studiów wyższych mają większe prawdopodobieństwo założenia własnej działalności gospodarczej (Cooper i in., 1994). Posiadanie wyższego wykształcenia ma pozytywny wpływ na odsetek samozatrudnienia i wysoką nadreprezentatywność osób z dyplomem szkoły wyższej w strukturze pracodawców (Bates, 1990; Grotkowska, Sztanderska, 2007; Cieślik, 2010). Dowiedziono także, że wyższe wykształcenie wyraźnie korzystnie oddziałuje na podejmowanie inicjatywy gospodarczej, zwłaszcza bezpośrednio po zakończeniu studiów. Już po czterech latach od uzyskania dyplomu nie ujawniał się statystycznie istotny wpływ umiejętności nabytych na studiach na podjęcie samozatrudnienia (Greene, Saridakis, 2008).

Podobnie liczne są prace, które dowodzą, że pozytywne znaczenie ukończenia studiów wyższych dla inicjowania własnej działalności gospodarczej jest przynajmniej niejednoznaczne. Chronologicznie najwcześniejszym kontrargumentem było to, że przez długi czas dyplom, stopień, kwalifikacje w znacznie większym stopniu warunkowały status podmiotu na najemnym rynku pracy niż poziom jego umiejętności w zakresie przedsiębiorczości (Dore, 1976 W: Greene, Saridakis, 2008). Legitymowanie się wyższym wykształceniem głównie generowało sygnał do pracodawcy, iż dana osoba będzie prawdopodobnie bardziej produktywna i przydatna niż inni kandydaci do pracy mający wykształcenie na niższym szczeblu (Spence, 1973).

Badania wykazały też, że koncepcje programowe kształcenia na poziomie wyższym zakładają wyposażenie absolwenta w wiele umiejętności intensywnie zogniskowanych na procesie zdobywania holistycznej wiedzy, jej popularyzacji i prowadzeniu badań paranaukowych. Uczelnie wyższe w planach oraz programach studiów częściej majoryzują kompetencje potrzebne do znalezienia i utrzymania pracy niż do kreowania własnego miejsca pracy. Nie implementowano powszechnie do programu studiów na każdym kierunku takich kursów, które szczególnie budowałyby kompetencje z zakresu zarządzania, przywództwa, pracy zespołowej, a które stanowią trzon umiejętności osoby prowadzącej własną firmę. To nie sprzyjało redukowaniu luk kompetencji marketingowych u studentów. Filozofia edukacji akademickiej epizodycznie nawiązywała do tzw. trzeciej misji, którą jest przygotowanie zarówno studentów, jak i pracowników naukowych do przedsiębiorczości (Banerski i in., 2009; Kostoglou, Siakos, 2012). Podobnie rozwój edukacji przedsiębiorczości na etapie akademickim oceniono także i w Polsce (Wach, 2008; Pietrzykowski, 2011). Testy kompetencji przeprowadzone wśród wielu absolwentów szkół wyższych dowodzą tego trendu i potwierdzają, że dana osoba dzięki dyplomowi szkoły wyższej jest znacznie lepiej przygotowana do bycia pracobiorcą niż przedsiębiorcą (Knight, 2001).

Kolejnym, istotnym argumentem, używanym przez sceptyków pozytywnego wpływu ukończenia studiów wyższych na poziom otwierania działalności gospodarczej, było to, że zgromadzony przez absolwentów kapitał edukacyjny zapewniał im zadowalającą gratyfikację finansową w pracy najemnej. Osoba z dyplomem ukończenia studiów wyższych mogła stosunkowo łatwo otrzymać satysfakcjonujące ją wynagrodzenie, które niemal zawsze było wyższe niż w wypadku samozatrudnienia - zwłaszcza w pierwszej, trudnej do oszacowania długości fazie funkcjonowania przedsiębiorstwa. Niechęć do oczekiwania najpierw na jakiekolwiek dochody, potem na zyski zapewniające stabilność finansową, zwłaszcza tuż po ukończeniu 
studiów przez młodych ludzi, jest dość duża i zrozumiała. Absolwenci chcą, aby ponoszone inwestycje we własną edukację szybko zapewniły im samodzielność finansową i odpowiedni standard życia. Dopóki poziom wynagrodzeń będzie rósł wraz z poziomem wykształcenia, dopóty absolwenci w zdecydowanej większości będą wybierali pracę najemną, ponieważ ta ścieżka zawodowa jest znacznie łatwiejsza niż prowadzenie działalności gospodarczej. Założenie i prowadzenie własnej firmy wiąże się z wysokim ryzykiem i stresem, wymaga dużego nakładu czasu i kapitału. Tezy te potwierdziły konkretne badania w kilku krajach. Przykładowo, w Szwecji absolwenci studiów wyższych ścieżkę samozatrudnienia postrzegają jako nieatrakcyjną, bowiem ciągle mogą oni podjąć dobrze płatną pracę (Greene, Saridakis, 2008). Podobną prawidłowość stwierdzono w Grecji i Wielkiej Brytanii, gdzie samozatrudnienie było zdecydowanie większe wśród osób z wykształceniem podstawowym i zawodowym, niż wyższym (Livanos, 2009). Z kolei w Portugalii rozpoznano, że wykształcenie wyższe osłabia prawdopodobieństwo przejścia z pracy etatowej do samozatrudnienia, które jest znacznie częstsze u osób ze średnim wykształceniem. Jest to konsekwencja wysokiej, w porównaniu z absolwentami szkół średnich, satysfakcji zawodowej (zwłaszcza z merytorycznego zakresu obowiązków) osób z dyplomem uniwersytetu (Amaral, Batista, 2006 W: Macieira, 2009). Także i w Polsce wykonano badania, w których dowiedziono, że ukończenie szkoły wyższej nie ma istotnego wpływu na wzrost samozatrudnienia ${ }^{2}$ (Czarnik, Turek, 2012).

\section{Uwarunkowania zewnętrzne}

Za niskie zainteresowanie samozatrudnieniem wśród absolwentów oraz małe spopularyzowanie tego modelu ścieżki kariery przez instytucje kształcące na poziomie akademickim odpowiadał także, dominujący w większości krajów wysoko rozwiniętych do końca lat 80. XX w., model doskonale prosperującej gospodarki opartej na dużych, często zbiurokratyzowanych korporacjach. Propagowano tezę, że jedyną racjonalną drogą do rozwoju zawodowego (zwłaszcza przez osoby z wyższym wykształceniem) było wspinanie się po szczeblach kariery w korporacji (Audretsch, Thurik, 2000). Ten homogeniczny kanon rozwoju kariery bardzo mocno utkwił w świadomości ludzi. Sprzyjały temu nie tylko doświadczenia i obserwacje rzeczywistości, lecz także liczne, bardzo popularne produkcje filmowe, które ukazywały spektakularne sukcesy zawodowe osób decydujących się na taką drogę zawodową. Załamanie takiego wzoru sukcesu na rynku pracy w dużej mierze nastąpiło przez nasilające się procesy globalizacji i rozwój gospodarki opartej na wiedzy. Znaczący wpływ miały także przemiany polityczne, prywatyzacja, destabilizacja rynku pracy i wystąpienie sytuacji kryzysowych (nietypowych), takich jak: wielkoskalowe bezrobocie, światowy kryzys gospodarczy (Greene, 2002). To te procesy najintensywniej indukowały wzrost przedsiębiorczości, mierzony przyrostem liczby firm. Przykładowo, w Wielkiej Brytanii był to blisko dwukrotny wzrost podmiotów gospodarczych: z 2,4 mln w 1980 r. do 4,5 mln w 2006 - jak ustalił Peiperl i inni, 2000 W: Greene, Saridakis, 2008. One także transformowały wizję kariery zawodowej w kierunku mniej homogenicznej, bardziej płynnej, wielowariantowej i podmiotowo skoncentrowanej.

Tak zatem stabilny i bezpieczny rynek pracy nie jest dobrym impulsem do otwierania działalności gospodarczej przez osoby z wyższym wykształceniem. Na tym założeniu oparto teorię ,push”, według której wysoka stopa bezrobocia na rynku pracy pozytywnie wpływa

\footnotetext{
${ }^{2}$ Ustalono natomiast, że do czynników sprzyjających zakładaniu własnej firmy należą: wiek równy 35 lat lub wyższy, pozostawanie w związku małżeńskim, posiadanie prawa jazdy, wykonywanie zawodu związanego z usługami lub z rolnictwem, wysoka samoocena kompetencji kierowniczych i samoorganizacyjnych (Czarnik, Turek, 2012: 46).
} 
na poziom samozatrudnienia, bowiem prowokuje tzw. efekt uchodźctwa. Ludzie, chcąc mieć źródło dochodu, decydują się na rozpoczęcie własnej działalności gospodarczej, uznając, że jest to dla nich jedyna alternatywa przed uniknięciem bezrobocia w dobie kryzysu. Wzrost liczby takich osób statystycznie zwiększa szanse na powodzenie, co w efekcie redukuje skalę bezrobocia w ogóle. Wskazane trudności na rynku pracy mogą pobudzać do samozatrudnienia wszystkie osoby, bez względu na poziom wykształcenia, niemniej kapitał wiedzy i umiejętności, zakumulowane w toku studiów, mogą być dla absolwentów uczelni wyższych dodatkowymi bodźcami do inicjowania takich działań (Amit, Muller, 1995). Istnieją także badania przeprowadzone w latach 90. XX w., które dowodzą, że w warunkach wysokiego bezrobocia na rynku pracy osoby z niższym wykształceniem znacznie częściej otwierały własną działalność gospodarczą, ponieważ były świadome swych relatywnie mniejszych szans na znalezienie zatrudnienia w porównaniu z absolwentami uniwersytetów (MacDonald, 1994). Podobne tezy postawiono także w Polsce, stwierdzając, że aktualna, niełatwa i perspektywicznie utrzymująca się na podobnym poziomie trudności sytuacja na rynku pracy może być podstawą do wzrostu oceny atrakcyjności ścieżki zawodowej przedsiębiorcy, szczególnie wśród absolwentów szkół wyższych (Cieślik, 2010).

Z kolei teoria „prosperity pull” wychodzi z odmiennego założenia. Zgodnie z nią jedynie stabilny i bezpieczny rynek pracy z niskim poziomem bezrobocia ośmiela do podejmowania prób samozatrudnienia (Amit, Muller, 1995). Empiryczne weryfikacje obu wymienionych teorii nie wskazały dotychczas jednoznacznie istotnego wpływu wyższego wykształcenia na poziom samozatrudnienia.

\section{Indywidualne cechy}

Istnieją w pracach naukowych argumenty przemawiające za tym, że przedsiębiorczość nie jest pochodną działania czynników zewnętrznych, a jedynie rezultatem immanentnych cech jednostki. W literaturze dominują trzy argumentacje takich poglądów:

1. Perspektywa idiosynkratyczna, według której przedsiębiorcy to osoby wyjątkowe, mające wrodzone cechy i zdolności kognitywne, charakteryzujące się ponadprzeciętną wolą walki i osiągnięć, bardzo wysokim poziomem optymizmu, naturalnym zmysłem przywódczym. Wymienione deskryptory nie są możliwe do wyuczenia w klasycznym systemie kształcenia.

2. Perspektywa kompetencji i atrybutów, w myśl której przedsiębiorca to osoba mająca wiele niezbędnych umiejętności, w tym zwłaszcza wolę sukcesu, pracowitość, umiejętność pracy w grupie, umiejętności komunikacyjne, kreatywność, zdolności przywódcze. Są to kompetencje, które mogą, ale nie muszą, być szczególnie rozwinięte w procesie edukacji zinstytucjonalizowanej, w tym na poziomie akademickim. Nie ma żadnych przeciwwskazań, by wykształcić je na innych poziomach kształcenia lub poza systemem kształcenia - w rodzinie czy w grupie społecznej. Mogą być one zarówno wypracowanymi kompetencjami, jak i wrodzonymi atrybutami danej osoby (Greene, 2002).

3. Perspektywa intuicji, która zakłada, że bycie przedsiębiorcą nie jest tylko pochodną wiedzy i umiejętność założenia własnej firmy, predyspozycji do realizacji takiej ścieżki zawodowej, ale głównie, jak ustalił Horne, 2000 W: Greene, Saridakis, 2008, ponadprzeciętnej intuicji $\mathrm{i}$ inteligencji emocjonalnej.

\section{Kapital spoleczny}

Zgodnie z teorią socjalizacji, kluczowe życiowe decyzje człowieka, do których zaliczyć należy założenie własnej działalności gospodarczej, wynikają przede wszystkim z kontekstu socjologicznego (społecznego) podmiotu oraz zdobytych przez niego wcześniej doświadczeń 
na rynku pracy. Zasadniczą rolę przypisuje się klimatowi przedsiębiorczości wytwarzanemu w rodzinie i pozytywnemu wpływowi doświadczenia prowadzenia firmy, przejawiającemu się powielaniem tej ścieżki kariery zawodowej przez dorosłe dzieci. Ponadto w sytuacji, gdy rodzice prowadzą/prowadzili własną działalność gospodarczą, ich dzieci zakładały swoje firmy wcześniej niż rówieśnicy, a przyjęte przez nich strategie działania były bardziej skuteczne. Jest to głównie efektem współuczestniczenia w prowadzeniu działalności przez rodziców, co skutkuje nie tylko naśladowaniem ich stylu pracy, lecz także krytyczną refleksją w tym zakresie. To buduje bagaż bezpośrednich doświadczeń i obserwacji, które zwiększają szanse na długofalowe powodzenie we własnej karierze zawodowej przedsiębiorcy (Macieira, 2009). Zależność ta nie odnosi się tylko do więzów krwi ale, przykładowo, do związków małżeńskich (Blanchflower, 2000; Livanos, 2009). Jak wskazują badania, nawet trudności członków rodziny w toku prowadzenia własnej działalności gospodarczej nie mają negatywnych reperkusji w postaci zamiany decyzji pokolenia dzieci w zakresie samozatrudnienia (DeWit, Van Winden, 1989).

Wykonano także badania stwierdzające pozytywny wpływ posiadania wcześniejszego doświadczenia zawodowego, zdobytego w pracy najemnej, na wybór kariery przedsiębiorcy. Obserwacja specyfiki pracy pracodawcy oraz czynne sprawdzenie siebie w roli pracownika często budzą zainteresowanie samozatrudnieniem, bez względu na to, czy praca najemna była dla danej osoby satysfakcjonująca, czy ją rozczarowała (Bates, 1995 W: Macierira, 2009).

\section{Przedsiębiorczość absolwencka - wyniki badań}

Na świecie wykonano nieliczne empiryczne badania, które eksplorowałyby zagadnienie stopnia wpływu ukończenia edukacji na poziomie wyższym na kreowanie postaw przedsiębiorczych i podejmowanie realnych kroków, mających na celu stworzenie sobie miejsca pracy (Greene, Saridakis, 2008). Dotychczas rozpoznano cechy demograficzne sprzyjające wyborowi ścieżki przedsiębiorcy w populacji z wyższym wykształceniem. I tak, stwierdzono, że własną działalność zakładają głównie osoby powyżej 30 roku życia, w tym najpowszechniej w wieku 35-45 lat i są to w znacznej przewadze mężczyźni (Le, 1999; Delmar, Davidsson, 2000).

Ustalono, że w 1983 r. poziom samozatrudnienia absolwentów szkół wyższych, mierzony po sześciu miesiącach od dnia zakończenia studiów, wynosił tylko 0,3\% (Brown, 1990). Ten niski odsetek przedsiębiorców w populacji nowo promowanych absolwentów był wówczas przede wszystkim rezultatem ich dobrej pozycji na rynku pracy i bardzo dużymi możliwościami wykonywania wysoko płatnej oraz niematerialnie satysfakcjonującej pracy najemnej. W końcu lat 90. XX w. odnotowano siedmiokrotny wzrost odsetka samozatrudnionych absolwentów (w Wielkiej Brytanii i Stanach Zjednoczonych), który kształtował się wówczas na poziomie 4,0\% (Greene, 2002). Najnowsze badania, wykonane w XXI w., pokazują, że ok. pół roku po zakończeniu studiów 2,1\% absolwentów prowadziło własną działalność gospodarczą, zaś po czterech latach odsetek ten wyniósł 3,2\%. Odsetek firm otworzonych przez absolwentów w interwale sześciu miesięcy od uzyskania dyplomu, które przetrwały i funkcjonowały nadal po czterech latach, wyniósł 29\%. Ci, którzy rozpoczęli własną działalność i ją zamknęli, nie decydowali się na ponowne założenie firmy przed upływem czterech lat (Greene, Saridakis, 2008).

W Polsce badania struktury osób pracujących na własny rachunek (poza rolnictwem, niezatrudniających innych osób) wydają się dowodzić znaczącej roli wyższego wykształcenia w podejmowaniu samozatrudnienia (Grotkowska, Sztanderska, 2007; Czarnik, Turek, 2012). Z kolei raport rejestrujący poziom przedsiębiorczości akademickiej, rozumianej jako prowadzenie własnych firm typu spin-off, spin-out, wskazuje, że był on równy $6 \%$ (9\% kadry naukowej i 2\% studentów ma własną firmę) (Banerski i in., 2009). 
Badania zmierzające do ustalenia poziomu zainteresowania studentów prowadzeniem własnej działalności dowodzą, że ten model kariery zawodowej jest przez nich bardzo często brany pod uwagę. Ponad $2 / 3$ polskich studentów $(73,2 \%)$ uważało się za osoby przedsiębiorcze $^{3}$. Aż $84 \%$ respondentów odpowiedziało, że gdyby miało wystarczającą wiedzę na temat zakładania własnej działalności, zrobiłoby to. Prawie połowa studentów (42,3\%) miała już pomysł na własną firmę i 26,9\% z nich zadeklarowało, że wybierze tę ścieżkę kariery po zakończeniu kształcenia (Kunasz, 2008). Studenci kierunków ekonomicznych ujawnili jeszcze intensywniej postawy proprzedsiębiorcze, bowiem wśród nich 78,7\% postrzegało się jako osoby przedsiębiorcze i aż 90\% twierdziło, że jedynym hamulcem otwierania własnej firmy jest dla niech niewystarczający zasób wiedzy w tym zakresie (Bernat, Kunasz, 2005). Wysokie zainteresowanie własną inicjatywą gospodarczą deklarowali również studenci Uniwersytetu Rzeszowskiego, wśród których 38,2\% osób kończących studia I stopnia i 39,8\% osób kończących studia magisterskie planowało założyć własną działalność (Badanie, 2012b). Mniejszy odsetek (9,5\%) studentów geografii za swój priorytet po zakończeniu studiów postawił sobie otworzenie własnej działalności gospodarczej (Piróg, 2012).

Jak pokazują badania losów zawodowych absolwentów wybranych uczelni w Polsce, optymistyczny obraz gotowości do podjęcia się prowadzenia własnej działalności wśród studentów w niewielkim stopniu odpowiada stanowi rzeczywistemu. Karierę przedsiębiorcy wybiera od kilku do kilkunastu procent nowo promowanych absolwentów. Dość wysokie odsetki osób prowadzących własną firmę 4 zanotowano wśród absolwentów Uniwersytetu Jagiellońskiego (10\%) (Ćwiąkalska i in., 2011), Politechniki Krakowskiej (5\% inżynierów; 6\% magistrów) (Badanie, 2012a), Akademii Górniczo-Hutniczej (5,4\%) (Wyniki, 2012) oraz Uniwersytetu Śląskiego (3,9\%) (Mazak, 2012). Niższy poziom samozatrudnionych zarejestrowano wśród absolwentów Uniwersytetu Rzeszowskiego (2,7\%) (Badanie, 2012c) i Uniwersytetu Pedagogicznego (2\%) (Losy, 2012). Nadzieję na wzrost odsetka przedsiębiorców w tej populacji przynoszą deklaracje prawdopodobieństwa założenia swojej firmy przez zarejestrowanych bezrobotnych absolwentów szkół wyższych. W województwie zachodniopomorskim aż 36\% z nich przyznało, że są gotowi do rozpoczęcia działalności gospodarczej (Poteralski, 2007). Brak jest jednak badań weryfikujących poziom realizacji tych deklaracji.

Na podstawie analizy wyników badań empirycznych należy stwierdzić, że aktywność polskich absolwentów szkół wyższych w otwieraniu działalności gospodarczej jest nieco wyższa niż pośród ich rówieśników w innych krajach.

\section{Podsumowanie}

Studia literatury dowodzą współwystępowania wielu czynników warunkujących wybór ścieżki zawodowej przedsiębiorcy przez absolwentów szkół wyższych i nie wskazują na jednoznacznie determinującą rolę posiadania dyplomu w tym procesie (Greene, Saridakis, 2008). Badania diagnostycznie pokazują, że na świecie w ciągu ostatniego 30-lecia odsetek nowo promowanych absolwentów prowadzących własną działalność gospodarczą wzrósł siedmiokrotnie i wynosi ok. 3-4\%. W Polsce odsetek ten jest wyraźnie zróżnicowany pomiędzy absolwentami poszczególnych uczelni i wynosi $2-10 \%$.

\footnotetext{
${ }^{3}$ Odsetek ten w innych krajach Europy Środkowo-Wschodniej wynosił: 79\% na Ukrainie, 75\% na Łotwie, $67,3 \%$ na Węgrzech, 64,6\% na Litwie i 60,2\% w Rosji.

${ }^{4}$ Dotyczy samozatrudnienia podjętego w okresie 6-12 miesięcy od dnia formalnego zakończenia danego stopnia studiów.
} 
Do dyskusji pobudza rozdźwięk między wysokim lub przynajmniej średnim zainteresowaniem samozatrudnieniem wśród studentów a wyraźnie niższym poziomem ich rzeczywistej aktywności w tym zakresie bezpośrednio po ukończeniu studiów. Wydaje się, że studia wyższe stymulują potrzebę i poczucie gotowości do założenia własnej firmy, lecz albo to oddziaływanie nie jest wystarczająco mocne, albo niwelują je inne czynniki. Zalicza się do nich zwłaszcza bariery mentalno-kulturowe, kompetencyjne, organizacyjne, prawne i finansowo-popytowe (Klimczuk-Kochańska, 2011). Ograniczeniem, które może być redukowane w toku kształcenia wyższego, jest bariera kompetencyjna. Działania zmierzające do zrealizowania tego celu powinny się skupiać przede wszystkim na dostarczaniu studentom konkretnych umiejętności operacyjnych, niezbędnych nie tylko do opracowania strategii swojej działalności gospodarczej, ale też do wdrożenia tej koncepcji w życie, utrzymania i rozwoju firmy.

Nasilające się trudności absolwentów szkół wyższych we wchodzeniu na rynek pracy wydają się być znaczącym argumentem, przemawiającym za potrzebą uzupełnienia misji uniwersytetu o przygotowywanie studentów do przedsiębiorczości pojmowanej jako aktywne zachowania umożliwiające samodzielne funkcjonowanie na rynku pracy, w tym także prowadzenie własnej inicjatywy gospodarczej.

\section{Literatura References}

Amaral, A.M., Baptista, R. (2006). Transitions from Paid-Employment into Entrepreneurship: An Empirical Study for Portugal. [In:] M. Dowling and J. Schmude (eds.) Empirical Entrepreneurship in Europe: New Perspectives, Edward Elgar.

Amit, R., Muller, E. (1995). Push and pull entrepreneurship. Journal of Small Business and Entrepreneurship, 12(4), 65-80.

Audretsch, D.B., Thurik, A.R., (2000). Capitalism and democracy in the $21^{\text {st }}$ century: from the managed to the entrepreneurial economy. Journal of Evolutionary Economics, 10(1-2), 17-34.

Badanie losów absolwentów PK. Studia II stopnia/jednolite magisterskie, rocznik 2012a. Wyniki z badania po roku od ukończenia studiów. http://www.kariery.pk.edu.pl/download,pl.htm (ostatni dostęp 20.09.2013 r.).

Badanie losów zawodowych absolwentów Uniwersytetu Rzeszowskiego z rocznika 2009/2010 po roku od zakończenia studiów. Biuro Karier Uniwersytetu Rzeszowskiego, Rzeszów, 2012c: http:// kariera.univ.rzeszow.pl/images/stories/raport\%20z\%20badania\%20losw\%20zawodowych\%20absolwentw\%20ur\%20rocznik\%2020092010\%20po\%20roku\%20od\%20zakoczenia\%20studiw.pdf (ostatni dostęp 20.09.2013 r.).

Badanie losów zawodowych absolwentów Uniwersytetu Rzeszowskiego. Pomiar początkowy absolwentów z rocznika 2010/2011. Biuro Karier Uniwersytetu Rzeszowskiego, Rzeszów, 2012b: http://kariera.univ.rzeszow.pl/images/stories/raport\%20z\%20badania\%20losw\%20zawodowych\% 20absolwentw\%20ur\%20pomiar\%20pocztkowy\%202010-2011.pdf (ostatni dostęp 20.09.2013 r.).

Banerski, G., Gryzik, A., Matusiak, K.B., Mażewska, M., Stawasz, E. (2009). Przedsiębiorczość akademicka. Raport z badania. Warszawa: PARP.

Bates, T. (1990). Entrepreneur Human Capital Inputs and Small Business Longevity. The Review of Economics and Statistics, 4, 551-559.

Bates, T. (1995). Self-employment entry across industry groups. Journal of Business Venturing, 10(2), 143-156.

Bernat, T., Kunasz, M. (2005). Realia gospodarcze a postawy przedsiębiorcze studentów. Wyniki badań. Zeszyty Naukowe Uniwersytetu Szczecińskiego, 408, Prace Katedry Mikroekonomii, 10, 95-109. 
Blanchflower, D.G. (2000). Self-Employment in OECD Countries. Labour Economics, 7(5), 471-505. Brown, R. (1990). Encouraging entrepreneurship: Britain's new enterprise program. Journal of Small Business Management, 28(4), 71-77.

Chrabąszcz, K. (2011). Przedsiębiorczość akademicka - drogą do sukcesu absolwentów szkół wyższych. Zeszyty Naukowe Małopolskiej Szkoły Wyższej w Tarnowie, 18(1), 197-208.

Cieślik, J. (2010). Przedsiębiorczość dla ambitnych. Jak uruchomić własny biznes. Warszawa: Wydawnictwa Akademickie i Profesjonalne.

Cooper, A.C., Gimeno-Gascon, F.J., Woo, C.Y. (1994). Initial human capital and financial capital as predictors of a new venture performance. Journal of Business Venturing, 9, 371-395.

Cranmer, S. (2006). Enhancing graduate employability: best intentions and mixed outcomes. Studies in Higher Education, vol. 31 (2), 169-184

Czarnecki, K.M. (2006). Psychologia zawodowej pracy człowieka. Sosnowiec: Wyd. Wyższej Szkoły Zarządzania i Marketingu w Sosnowcu.

Czarnik, Sz., Turek, K. (2012). Wyksztatcenie, praca i przedsiębiorczość Polaków. Na podstawie badań zrealizowanych w 2012 roku w ramach III edycji projektu Bilans Kapitatu Ludzkiego, Warszawa: PARP.

Ćwiąkalska, M., Hojda, P., Ostrowska-Zakrzewska, M. (2011) Losy zawodowe absolwentów Uniwersytetu Jagiellońskiego. Rocznik 2008/2009. Absolwenci studiów magisterskich i licencjackich. Raport z badania. Kraków: Biuro Karier UJ.

Delmar, F., Davidsson, P. (2000). Where do they come from? Prevalence of and characteristics of nascent entrepreneurs. Entrepreneurship \& Regional Development, 12, 1-23.

DeWit, G., Van Winden, F.A. (1989). An empirical analysis of self-employment in the Netherlands. Small Business Economics, 1, 263-72.

Dore, R. (1976). The diploma disease: Education, qualification and development. Berkeley: University of California Press.

Greene, F. (2002) An investigation into enterprise support for younger people, 1975-2000. International Small Business Journal, 20(3), 315-336.

Greene, F., Saridakis, G. (2008). The role of higher education skills and support in graduate self-employment. Studies in Higher Education, 33(6), 653-672.

Grotkowska, G., Sztanderska, U. (2007). Samozatrudnienie. W: Edukacja dla pracy. Raport o rozwoju społecznym Polska 2007, Warszawa: UNDP, 115-116.

Henley, A. (2009) Switching Costs and Occupational Transition into Self-Employment, IZA Discussion Papers 3969, Institute for the Study of Labor (IZA), 1-39.

Horne, M. (2000). Enterprise learning. London: Demos.

Klimczuk-Kochańska, M. (2011). Bariery rozwoju przedsiębiorczości akademickiej na przykładzie podlaskich uczelni. Zeszyty Naukowe WSEI, Seria Ekonomia, 3, (1/2011), 73-98.

Knight, P.T. (2001). Employability and quality. Quality in Higher Education, 7(2), 93-95.

Kostoglou, V., Siakos, E., (2012). Investigating higher education graduates' entrepreneurship in Greece. Annals of Innovation \& Entrepreneurship, 3, 1-7.

Kunasz, M. (2008). Potencjat proprzedsiębiorczy studentów i klimat wobec przedsiębiorczości w wybranych krajach Europy Środkowo-Wschodniej. W: T. Bernat, J. Korpysa, M. Kunasz (red.) Przedsiębiorczość studentów w Polsce $i$ w wybranych krajach Europy Środkowo-Wschodniej. Szczecin: Katedra Mikroekonomii Uniwersytetu Szczecińskiego, 126-136.

Le, A.T. (1999). Empirical studies of self-employment. Journal of Economic Surveys, 13, 381-416.

Livanos, I. (2009). What determines self-employment? A comparative study. Applied Economics Letters, 16(3), 227-232.

Losy zawodowe absolwentów Uniwersytetu Pedagogicznego. Rocznik 2010/2011. Raport z badania. Kraków, 2012.: http://bks.up.krakow.pl/htmlarea/uploaded/Raport_absolwenci2011_wszyscy.pdf.

MacDonald, R. (1994). Fiddly jobs, undeclared working and the something nothing for the society. Work, Employment and Society, 11(4), 615-638.

Macieira, M.H.C (2009). The determinants of self-employment. Universidade Tecnica de Lisboa.

Mazak, M. (2012). Badanie losów zawodowych absolwentów Uniwersytetu Ślaskiego w Katowicach. Absolwenci 2009/2010 - 1 pomiar. Biuro Karier Uniwersytetu Śląskiego. 
Minniti, M., Bygrave, W. (2001). A dynamic model of entrepreneurial learning. Entrepreneurship Theory and Practise, 25(3), 5-16.

Peiperl, M., Arthur, M., Goffee, R., Morris T. (eds.). 2000. New conceptions of working lives. New York: Oxford University Press.

Pietrzykowski, M. (2011). Entrepreneurship in Higher Education - case of Poland. In: M. Drabic, M. Pietrzykowski (eds.) Fostering Education in Entrepreneurship, Poznań: Bogucki Wydawnictwo Naukowe, 113-128.

Piróg, D. (2012). Aspiracje i plany zawodowe młodzieży akademickiej w Polsce na przykładzie studentów geografii. W: A. Dudak, K. Klimkowska, A. Różański (red.) Przygotowanie zawodowe młodych pedagogów, Kraków: Oficyna Wydawnicza Impuls, 125-144.

Poteralski, J. (2007). Przedsiębiorczość absolwentów wyższych uczelni w województwie zachodniopomorskim. W: J. Poteralski (red.) Przemiany rynku pracy w kontekście procesów społecznych i gospodarczych. Szczecin: Katedra Mikroekonomii Uniwersytetu Szczecińskiego, 203-211.

Rożnowski, B. (2009) Przechodzenie młodzieży z systemu edukacji na rynek pracy $w$ Polsce. Analiza kluczowych pojęć dotyczacych rynku pracy u młodzieży, Lublin: Wyd. KUL.

Spence, M. (1973). Job Market Signalling, The Quarterly Journal of Economics, 87(3), 355-374.

Strojny, J., Horska, K. (2012). Przedsiębiorczość a edukacja akademicka - analiza badań studentów Wydziału Zarządzania studiów I stopnia Politechniki Rzeszowskiej. Rola przedsiębiorczości w edukacji. Przedsiębiorczość - Edukacja, 8, 78-85.

Sztumski, J. (1999). Socjologia pracy. Katowice: Wyd. GWSH.

Wach, K. (2008). Entrepreneurship Education in Poland, "ERENET Profile", vol. III, 3(11), 36-44.

Wyniki badań losów zawodowych absolwentów studiów stacjonarnych II stopnia Akademii Górniczo-

-Hutniczej w Krakowie, rocznik 2012: http://www.ck.agh.edu.pl/omkz/2st2012.pdf.

Danuta Piróg, dr, adiunkt w Instytucie Geografii, Uniwersytet Pedagogiczny w Krakowie.

Zainteresowania naukowe autorki dotyczą przede wszystkim zróżnicowania kulturowego Europy i tożsamości jej mieszkańców, przygotowania kandydatów na nauczycieli geografii i przyrody do przyszłej pracy zawodowej oraz efektywności studiów geograficznych w aspekcie potrzeb rynku pracy. Swoje doświadczenie naukowe pogłębiała przez czynny udział lub kierowanie krajowymi i międzynarodowymi projektami badawczymi. Aktualnie zajmuje się przede wszystkim wielowymiarowymi analizami czynników warunkujących procesy tranzycji absolwentów szkół wyższych na rynek pracy.

Danuta Piróg, PhD, an assistant professor at the Pedagogical University of Krakow (Institute of Geography).

The author's research interests are focus on the intercultural education, European education, practical preparation of students (candidates for the profession of geography teachers), and the effectiveness of geographical studies in the context of needs of the labour market.

She has been a member of various scientific projects on the national and European level. Currently her scientific surveys are devoted to multidimensional analysis of determinants of she graduates transition into the labour market.

Adres/Address: Uniwersytet Pedagogiczny im. Komisji Edukacji Narodowej w Krakowie Instytut Geografii

ul. Podchorążych 2

30-084 Kraków, Polska

e-mail: dbutryn@up.krakow.pl 